\title{
Four Seasons for Schwann Cell Biology, Revisiting Key Periods: Development, Homeostasis, Repair, and Aging
}

\author{
Gabriela Sardella-Silva ${ }^{1,2}$, Bruno Siqueira Mietto ${ }^{3}(D)$ and Victor Túlio Ribeiro-Resende 1,2,* $^{1}$ \\ 1 Instituto de Biofísica Carlos Chagas Filho, Universidade Federal do Rio de Janeiro, Rio de Janeiro 21941-902, \\ RJ, Brazil; gabrielasardella@biof.ufrj.br \\ 2 Núcleo Multidisciplinar de Pesquisa em Biologia (Numpex-Bio), Campus de Duque de Caxias Geraldo \\ Guerra Cidade, Universidade Federal do Rio de Janeiro, Duque de Caxias 25255-030, RJ, Brazil \\ 3 Instituto de Ciências Biológicas, Universidade Federal de Juiz de Fora, Juiz de Fora 36036-900, MG, Brazil; \\ bruno.mietto@ufjf.edu.br \\ * Correspondence: vtulio@biof.ufrj.br; Tel.: +55-21-39386594
}

Citation: Sardella-Silva, G.; Mietto, B.S.; Ribeiro-Resende, V.T. Four Seasons for Schwann Cell Biology, Revisiting Key Periods: Development, Homeostasis, Repair, and Aging. Biomolecules 2021, 11, 1887. https:// doi.org/10.3390/biom11121887

Academic Editors: Seth Blackshaw and Michele Fornaro

Received: 27 October 2021 Accepted: 10 December 2021 Published: 15 December 2021

Publisher's Note: MDPI stays neutral with regard to jurisdictional claims in published maps and institutional affiliations.

Copyright: (c) 2021 by the authors. Licensee MDPI, Basel, Switzerland. This article is an open access article distributed under the terms and conditions of the Creative Commons Attribution (CC BY) license (https:/ / creativecommons.org/licenses/by/ $4.0 /)$.

\begin{abstract}
Like the seasons of the year, all natural things happen in stages, going through adaptations when challenged, and Schwann cells are a great example of that. During maturation, these cells regulate several steps in peripheral nervous system development. The Spring of the cell means the rise and bloom through organized stages defined by time-dependent regulation of factors and microenvironmental influences. Once matured, the Summer of the cell begins: a high energy stage focused on maintaining adult homeostasis. The Schwann cell provides many neuron-glia communications resulting in the maintenance of synapses. In the peripheral nervous system, Schwann cells are pivotal after injuries, balancing degeneration and regeneration, similarly to when Autumn comes. Their ability to acquire a repair phenotype brings the potential to reconnect axons to targets and regain function. Finally, Schwann cells age, not only by growing old, but also by imposed environmental cues, like loss of function induced by pathologies. The Winter of the cell presents as reduced activity, especially regarding their role in repair; this reflects on the regenerative potential of older/less healthy individuals. This review gathers essential information about Schwann cells in different stages, summarizing important participation of this intriguing cell in many functions throughout its lifetime.
\end{abstract}

Keywords: Schwann cells; peripheral nervous system; development; homeostasis; regeneration

\section{Introduction}

Schwann cells are the principal glia of the peripheral nervous system (PNS), which virtually orchestrates most, if not all, pathophysiological processes that develop in the nerve (as reviewed in [1]). Schwann cells outnumber the other non-neuronal cells that populate the nerve (i.e., macrophages and fibroblasts) and are uniquely positioned side-by-side along the axonal projections, making these cells a great partner for neuronal physiology and nerve tissue homeostasis (as reviewed in [2]). Regarding peripheral neuropathies, the success of nerve regeneration is attributed to changes in Schwann cell responses, including their ability to secrete inflammatory mediators, to clear cellular and myelin debris and to produce a broad range of regenerative factors, making modified Schwann cells great orchestrators of nerve repair [3-5]. In addition to their role in the injured microenvironment, several reports also identify mutual communication between Schwann cells and axons, with the transferring of cargos and metabolites from glia to the axon, which are crucial for the maintenance of axonal integrity and function [6,7], (for review, see [8]). Finally, all this intense biological activity has natural cell consequences generated by mitochondria-derived oxidative stress. The cells acquiring their aging phenotype lose the capacity to react and orchestrate most of their abilities to support homeostasis, degeneration, and regeneration. The importance of Schwann cells to peripheral nerve function is unquestionable, and for 
this matter, this review will focus on the four key periods of nerve biology (development, homeostasis, repair, and senescence) and how Schwann cells modulate and are influenced by these phases. Finally, in this review, we find that Schwann cell biology could be philosophically correlated with year seasons because, in this context, the energy levels are very similar. Therefore, this allows us to analyze scientific data about Schwann cells and generate a dynamic text on its biology.

\section{Spring for Schwann Cells: The Development}

Spring is the season in which all beauties naturally arise, starting from an innate genetic program that is accompanied by and influenced by "the practicing". These complementary intricate interactions between nature and nurture, applied to all cells over time throughout body development, generate distinct cellular specializations, including those in the peripheral nervous system (PNS). Therefore, the appearance and development of all cells in the PNS recollect the spring season when a great cell biology orchestra is playing very well tuned and synchronized processes to define the fate and function of these cells.

Schwann cells, in addition to melanocytes, dorsal root ganglion (DRG) neurons, autonomic neurons, and chromaffin cells, all originate from neural crest cells [9-13], whose migratory pattern is determined by bone morphogenetic proteins (BMPs) [14,15], Wnt, and FGF signaling [16-22]. The glial fate starts to be established once the migration initiates, as they migrate ventrally alongside autonomic neurons and chromaffin cells, while melanocytes and DRG neurons migrate by a lateral pathway [12,13]. Furthermore, the melanocytic lineage expresses c-Kit receptors, while it has been shown that the neural-fate is associated with TrkC expression on these cells [10]. After migrating and directing to the glial lineage, the neural crest cells undergo an organized and time-specific differentiation process that goes from the embryonic to the post-natal stages. The main signaling pathway seems to be the Notch-Delta/neuregulin/endothelin-3 [23-28], which acts by orchestrating the expression of several transcription factors, such as SOX10, a transcriptional factor that marks the transition from neural crest cell to a committed glial precursor $[29,30]$. At about E14 (rats) and E12.5 (mouse), these cells turn into Schwann cell precursors at the equivalent time when the nerve develops, associating themselves with the first growing axons. When compared to neural crest cells, Schwann cells start expressing several different molecules, such as Cadherin 19 (Cad19) and GAP43, stop being associated with and dependent on the extracellular matrix (ECM) and begin to depend on the survival factor secreted by the growing axon, Neuregulin 1 (NRG1), via activation of receptors ErbB2/ErbB3 [11,24,26,31,32]. These precursors are important for the fasciculation and long-term survival of both sensorial and motor neurons, through the secretion of GDNF and NT3 [33-36]. These cells rapidly differentiate into the next phenotype, the immature Schwann cell (around E17 in rats), which lasts up until birth when the cells acquire the terminal differentiation. As they go from precursors to immature cells, they progressively express S100B protein, which, from this point on, remains expressed even on terminally differentiated cells [11]. They also become independent from the axonal survival signaling, as they stop responding to NRG1 and start an autocrine survival circuit that includes a broad range of neurotrophic factors, including FGF, IGF, ET, PDGF, and NT3 [37-39]. This ability of secreting neurotrophins, initiated during Schwann cells development, will print out a molecular signature on these cells, allowing them to recapitulate part of this genetic program when the nerve is perturbed by an injury (as reviewed in [1]).

At this stage, the basal lamina becomes organized, and the Schwann cells participate in the arteriogenesis signaling alongside neurons by secreting VEGF $[40,41]$, promote the differentiation of the connective tissue by the expression of Dhh [42], and organize the radial sorting, a crucial step to the correct myelination of the PNS [43]. On this radial sorting event, the immature Schwann cells group axons and then proceed to proliferate and infiltrate through these groups, resulting in events known as fasciculations, when large caliber axons are segregated from the bundles that later become non-myelinated Remak bundles. This segregation is the cause of the well-known 1:1 ratio observed in 
myelinated axons. Thereafter, the immature Schwann cells stop their proliferation and begin the production of basal lamina in the process of defasciculation [43-45]. The signaling for the proper sorting organization derives from components found in the basal lamina, as well as from the axons, including Wnt and R-spondins signaling pathways [45-51]. After birth, this radial sorting continues up until a few post-natal days [43].

After birth, the myelination phenotype of the nerve is initiated in a process driven by signals provided by axons that promote the immature Schwann cells to a myelinating or non-myelinating phenotype, through the biochemical marker of axonal caliber NRG1 type III. Large caliber axons express high levels of type III NRG1 on their surfaces, activating ErbB2/ErbB3 receptors present on the Schwann cell membranes in a way that overcomes the minimum threshold required for myelination induction [52]. After surpassing the threshold, the more NRG1 is expressed, the thicker the myelin sheath will be [53]. However, small caliber fibers express low levels of NRG1 and do not reach this minimum signaling threshold necessary to trigger Schwann cells to enter the myelination program. In fact, these axonal segments are organized in groups, assembled by one non-myelinating Schwann cell, forming the known Remak bundles by the end of the radial sorting period, in rodents [52].

The external signaling to a myelinating phenotype leads to the expression of many molecular regulators. The transcriptional factor SOX10 acts in synergy with factors Tst1/Oct-6/SCIP (also called Pou3f1) and Brn2 (also called Pou3f2), expressed in immature cells, by bounding to the myelinating Schwann cell element (MSE) that directs expression of another transcriptional factor, Krox20 [54-56]. Another pathway leads to this same terminal effect, as NRG1 has been shown to activate the PLC- $\gamma$ pathway, dephosphorylating the transcriptional factors NFATc3 and NFATc4, the latter also being capable of synergically interacting with SOX10, ending in Krox20 activation [57]. NRG1 also regulates expression of Krox20 by phosphorylating Yin Yang 1, a factor that also binds to the MSE [58]. Krox20, also known as Egr2, is the well-stablished main regulator of myelination promotion and maintenance, as it needs to be constantly expressed [59-61].

After the long spring and intricate cell-cell and cell-matrix interactions, finally, the nerve is ready to perform its function by having Schwann well-formed and positioned cells support the nerve in health and disease.

\section{Summer for Schwann Cells: Adult Homeostasis}

The adult stage of the nerve is a period of high energy flow with great part coming from Schwann cell metabolism in its mature phenotype, permitting the functionality of the adult peripheral nerve. In addition to their role in being wrapped around axons, Schwann cells are also responsible for energy storage and delivery, providing the necessary metabolic coupling for neuronal function and homeostasis (as reviewed in [62]). This neuron-Schwann cell bidirectional communication is a highly energetic rout, such as the summer period.

Schwann cells are key players on the maintenance of the PNS homeostasis (as reviewed in [63]). It has been demonstrated that Schwann cells, as well as their precursors, secrete neurotrophic factors, such as GDNF and NT3, which are crucial for the survival of both sensitive and motor neurons [33,35]. Myelinating Schwann cells are involved in many processes, such as the phosphorylation of axonal neurofilaments [64], and they also express the myelin-associated protein (MAG) that regulates axonal caliber [65]. One important regulatory role of these cells is the formation of the nodes of Ranvier, by inducting nodal membrane molecular specialization processes, such as the clustering of sodium channels. Surprisingly, this event occurs in a contact independent manner, through the secretion of both channel-forming factors, as well as surface molecules that restrict the spatial distribution of these channels $[66,67]$.

Similar to what happens in neuronal and other glial types, besides the myelinating/nonmyelinating profiles, it has been shown that myelinating Schwann cells present different patterns of growth factor production accordingly to sensory or motor association preference and in a central-peripheral axis manner, further dividing them in subtypes $[68,69]$. 
While oligodendrocytes are important to the metabolic support of central axons by offering substrates that are glycolysis-derived, but not originated from mitochondrial respiration $[70,71]$, Schwann cells participate in the metabolic support of peripheral axons in a mitochondrial dependent pathway [72]. Mitochondrial disruption has been indicated to cause demyelination, altered stress response, neuroinflammation, and axon degeneration [6,73] (for review, see [8]), which can be linked to the role of Schwann cell metabolism over pathologies such as the diabetic neuropathy [74]. Furthermore, the requirement of iron transfer from Schwann cells to axonal mitochondria for proper axonal physiology and regeneration was recently shwon [75]. In fact, a molecular pathway involved in the axon metabolic maintenance by Schwann cells was demonstrated to be the liver kinase B1 (LKB1) and its downstream target AMP activated protein kinase, LKB1AMPK, which is altered in many neuropathologies and aging [76].

The summertime for Schwann cells based on the description above can be sustained throughout the adult life, but as demonstrated over the last few decades, there are multiple aspects that can trigger a summer fading out and bringing up these cells to the next season, where pathogens, injuries, or metabolic diseases will trigger changes in Schwann cells phenotypes, adapting peripheral nerves to the degenerative and regenerative process. This is Autumn.

\section{Autumn for Schwann Cells: The Degeneration for a Potential Regeneration}

Unlike what is observed in the injured CNS, the PNS has great regenerative potential, even though it may occur in an incomplete or non-functional manner [77] (for review, see [78]). This re-growing potential is of great importance, as the PNS per se does not have bone protection, such as its central counterpart, leaving the peripheral tissue under severe risk, ranging from either external or internal traumatic origins, such as infections, genetic, and metabolic disorders. Those misfortunes somehow bring the autumn season to Schwann cells, and their plasticity is fundamental for proper degenerative processing, with positive consequences for regenerative ability.

Adult Schwann cells have an autocrine survival circuit that is of vital importance during the occurrence of injury [37-39]. After nerve injury and subsequent distal axon degeneration, these terminally differentiated cells signaled by the loss of axonal contact become part of the regenerative program of the PNS, through the ability of shifting into a regenerative immature-like phenotype, the repair Schwann cell $[79,80]$. After axonal traumatic injury, both CNS and PNS go through a degenerative process named Wallerian degeneration [81], which is markedly slow in the CNS [82-85], affecting the regeneration potential of central neurons. This degeneration on the mammal PNS is characterized by a sequence of events that go from $36 \mathrm{~h}$ to $7-14$ days post injury $[83,86,87]$, while on the CNS, it can take anywhere between months and years [88,89]. In the PNS Wallerian degeneration process, initial axonal degeneration is followed by myelin degradation. In addition to the contribution of macrophages to the overall removal of myelin and axonal debris, Schwann cells ingest myelin ovoids by a broad range of receptor-mediated phagocytosis [90,91] and by activating the intracellular autophagic myelin clearance [92,93]. Macrophage recruitment, activation, and clearance of tissue debris is also driven by Schwann cells, as they secrete inflammatory cytokines and chemokines that attract the hematogenous macrophages and induce proliferation of resident macrophages [3,94]. These Schwann cells lacking axonal contact also proliferate transiently and transdifferentiate into the repair phenotype [95]. The transcription factor c-Jun is considered the key orchestrator of the repair phenotype differentiation as it regulates a series of regeneration-related genes for different Wallerian degeneration steps: myelin clearance, neuronal survival, formation of Büngner bands, and axonal regrowth [4]. c-Jun is also a known negative regulator of the key myelin transcription factor Krox20 [96], as well as other myelin proteins, such as MBP and MPZ. While signaling the downregulation of myelination genes and myelin-forming elements, such as Krox20, MPZ, and MBP, it also upregulates immature markers, such as NCAM and p75NTR, indicating the dedifferentiated character of these cells [4]. To support 
the regeneration process, c-Jun also controls the known post-injury secretion of support growth factors, such as BDNF and GDNF [4], with other growth factors, such NGF, VEGF, and IGF, which are also being upregulated. Interestingly, Schwann cells from different fibers not only differ in their growth factor expression levels on homeostasis but also after injury, as was shown by Hoke et al. (2006) [69] and Brushart et al. (2013) [68]. Finally, these cells proliferate and shift their morphology to an elongated shape that is three-fold larger than the average mature Schwann cell. This is fundamental to the formation of the Büngner bands that act as a physical support, like a rail, to the reconnection of axons to their target tissues [79].

In physiological conditions, CNS and PNS axons are myelinated by different glial cells. While Schwann cells myelinate peripheral axons, the same axonal ensheathment is stablished by oligodendrocytes over the CNS $[97,98]$. Other than sharing this myelinating property, these two cells have different origins, morphology, and molecular profile [99]. These properties confer a vastly different response when it comes to repair. Different from the Schwann cell, oligodendrocytes do not help the myelin clearance process, nor do they support axons reconnecting to their lost targets. Due to the loss of axonal contact in degeneration, these cells enter an apoptotic or quiescent state. Therefore, the presence of myelin debris and its growth-inhibitor molecules, alongside the absence of axonal guidance, provide a very unfavorable environment to axonal regrowth [100-103]. However, endogenous Schwann cells were found inside the CNS both in animal models [104] and humans [105], associated as an occurrence (mostly on the spinal cord) after conditions of various origins that result in demyelination [106-109] or axonal injury [110]. The most common thought was that these cells migrate from the PNS into the CNS over pathologies and lesions to offer a similar regenerative role exhibited on the PNS. This opened a series of studies evidencing the transgression, remyelinating, and regenerating capacities of these cells in many different pathologies and conditions [106-120], as well as their regenerativeremyelinating potential after exogenous addition [121-127].

Although this PNS-CNS migration does happen, these PNS Schwann cells have been seen to colonize the more external portions of the spinal cord, on areas closer to the CNS-PNS interface [128], indicating that PNS-Schwann cell migration within the CNS is somehow limited. Recently, it has been shown through ectopically-placed PNS-Schwann cells that migration in the CNS is mediated by Eph/ephrin signaling, using blood vessels as a preferential substrate [129]. The Eph/ephrin interactions guide the migration because they can work both as positive or negative adhesion signals in many cell-cell adhesion events [130], and, in this scenario, it works by not only favoring the association to the blood vessels but also by the avoidance of CNS myelin. CNS myelin contains EphrinB3, an axon-growth inhibitor molecule, which acts through Schwann cell Eph receptors, EphA4 and EphB6, causing reduced adhesion and cell processes formation. However, the same EphrinB3, through interactions with integrin $\beta 1$, can improve Schwann cell adhesion to the perivascular fibronectin. Myelin was shown to upregulate expression of integrin $\beta 1$ and repel Schwann cells through its myelin-associated glycoprotein (MAG) [129]. Moreover, it is well known that MAG is also an anti-axon regeneration protein that binds to Schwann cells with high-specificity and promotes p75 cleavage, lacking Schwann cell migration, with consequent cell death [131].

As mentioned before, PNS Schwann cells have been identified mostly on the outer regions of lesions, nearer to PNS connections [128]. Gilmore et al. (1982) [115] observed time-dependent differences in Schwann cell distribution and myelin maturation over the lesion area. They encountered Schwann cell and mature myelin firstly on the outer portions, changing patterns in a dorsal-ventral direction. Blakemore et al. (1987) [132] suggested that these cells could either be Schwann cells or cells capable of becoming Schwann cells, once the demyelinated spinal cord presented Schwann cell remyelination after injections of CNS cells.

The remaining question is: where do these Schwann cells encountered in the center of CNS lesion sites come from? Recently, it has been shown that, surprisingly, these 
cells have a different origin. According to studies on both spinal cord injury [128] and demyelination [133], Schwann cells in the CNS can also be derived from oligodendrocyte precursor cells (OPCs), a fact observed using fate-mapping studies on the OPCs marker platelet-derived growth factor receptor $\alpha$ (PDGFR $\alpha$ ). Thus, besides forming remyelinating oligodendrocytes, OPCs originate most of the remyelinating Schwann cells, producing functioning cells with positive peripheral myelin marker P0 and characteristic morphology [128]. Interestingly, so far, these OPC-derived Schwann cells have been evidenced to retain two features of OPCs: the potassium channel current and $\mathrm{O} 4$ and A2B5 ganglioside higher expression. These cells also seem to present lower expression of GFAP when compared to its peripheral relative [134]. The mechanisms involved in this OPC-derived Schwann cell differentiation have been studied and might be due to the disbalance between the BMP/Wnt pathway and its antagonist, Sostc1. The proposed mechanism is that demyelination would cause upregulation of BMP4 in OPCs over the loss of homeostasis, which, in the absence of Sostdc1, expressed by reactive astrocytes, leads them to differentiate into Schwann cells [135]. Astrocytes also regulate the maintenance of CNS specificity, balancing oligodendrocyte and Schwann cell differentiation [136]. The molecular mechanisms for this balance seems to work through STAT3 signaling (as reviewed in [137]). Importantly, Schwann cells not only promote the remyelination process itself but allow later oligodendrocyte remyelination [118].

In addition to CNS myelin, astrocytes provide another barrier to Schwann cell infiltration. Firstly, astrocytes constitute the glia limitans (GL) that delimitate CNS and PNS compartments (as reviewed in [138]), therefore limiting PNS-derived Schwann cells entry. They also form a barrier over blood vessels [139]. CNS and PNS-Schwann cell migration and remyelination can only occur in astrocyte-free zones, provided either by astrocyte death, following injury or disease [109], or by irradiation or chemical ablation $[106,114,115,120]$. In fact, CNS lesion sites are knowingly delimitated by glial scar [140-145], constituted of reactive astrocytes, which could both possibly break the GL barrier [119] and delimitate the area so that Schwann cells do not spread beyond the lesion site [146]. This astrocyte barrier blocks the passage of Schwann cells but also the complete regrowth of axons, therefore challenging regeneration [141,142]. This barrier is not only physical but also molecular, having been linked to NCAM [147-150], PI3K-Akt signaling pathway through the mediation of neuregulins, and FGF [151], interaction between astrocytes EphrinAs and Schwann cell receptors EphA4 and EphA7 [152], and the presence of chondroitin-sulfate proteoglycans [153-156].

The first three seasons naturally require intense mitochondrial activity to provide enough energy to support such a complex and well-orchestrated biological process. It has been well understood that there are age-related drawbacks thar are linked to the accumulated levels of reactive oxygen species (ROS).

\section{Winter for Schwann Cells: Aging}

The aging of Schwann cells is not only related to the lifetime of cells from an elderly animal. This may be a winter in the right period, remarkably anticipated by a hostile modified environment or genetic/infected disorder. Altered metabolic patterns, reduced adaptation to stress, accumulation of damaged proteins, lipids, and DNA, as well as pathobiological and traumatic aspects, can accelerate cellular senescence and neurodegeneration, disturbing Schwann cell ability to support distinct aspects of peripheral nerve homeostasis, degeneration, and regeneration.

It is no novelty that the process of aging brings to the whole body, including the peripheral nerves, complex morphophysiological alterations. While it has been shown that many of these alterations include Schwann cells, the molecular mechanisms involved are still poorly elucidated. Even on physiological conditions, aging has been shown to affect nerve fibers with reduced function. This age-related deficit seems to be related to loss of oxidative damage protection and/or repair [157], an altered transcriptional map, 
especially on lipid metabolism and immune response [158], and loss of the heat shock protein, alphaB-crystallin $(\alpha B C)[159]$.

However, what has well-demonstrated is how aging affects the regenerative potential of the PNS by mainly altering the Schwann cell and its plasticity capacity, alongside modifying the connective tissue and macrophages [160]. Slow, delayed, and/or incomplete regeneration of aging injured nerves were thought to be due to the loss of the axon intrinsic regeneration capacities over aging. However, this poor regenerative capacity is associated with the unfavorable environment offered by aged Schwann cells, such as reduced debris clearance and decreased production of neurotrophic and growth factors [160], once those aged axons regrow normally in favorable conditions [160,161]. In fact, aging changes the normal occurrence of Wallerian degeneration by altering the regular molecular regeneration program of Schwann cells, therefore affecting multiple aspects of their differentiation towards the repair phenotype. When compared to Schwann cells from young, injured nerves, aged Schwann cells fail to upregulate pro-regenerative genes related to growth factors and mitosis; they also failed to downregulate myelin genes, an important step to enter the regenerative process [160]. The repair-associated transcription factor c-Jun shows a different acute regulation pattern in aged animals, which is aligned to the similarities seen in the transcriptional profiles of aged and c-Jun KO mice after injury $[91,160,162]$. This different environment during aging also affects the myelin clearance, not only by the Schwann cells but also because it alters the macrophage attraction and, therefore, immunomodulation $[160,163,164]$. Additionally, not only do Schwann cells age, but also the macrophage population, and it has been seen that both senescent Schwann cells and macrophages present reduced phagocytic capacities [160,164].

When a full year equivalent of a Schwann cell's life has passed, it is unquestionable that this cell is not only a member of the peripheral nervous system's philharmonic, but, in fact, it is its own conductor (Figure 1). Understanding it as a whole, all its potential and all its limitations, is an open door to the exploration of its many possibilities as a tool for regenerative medicine.

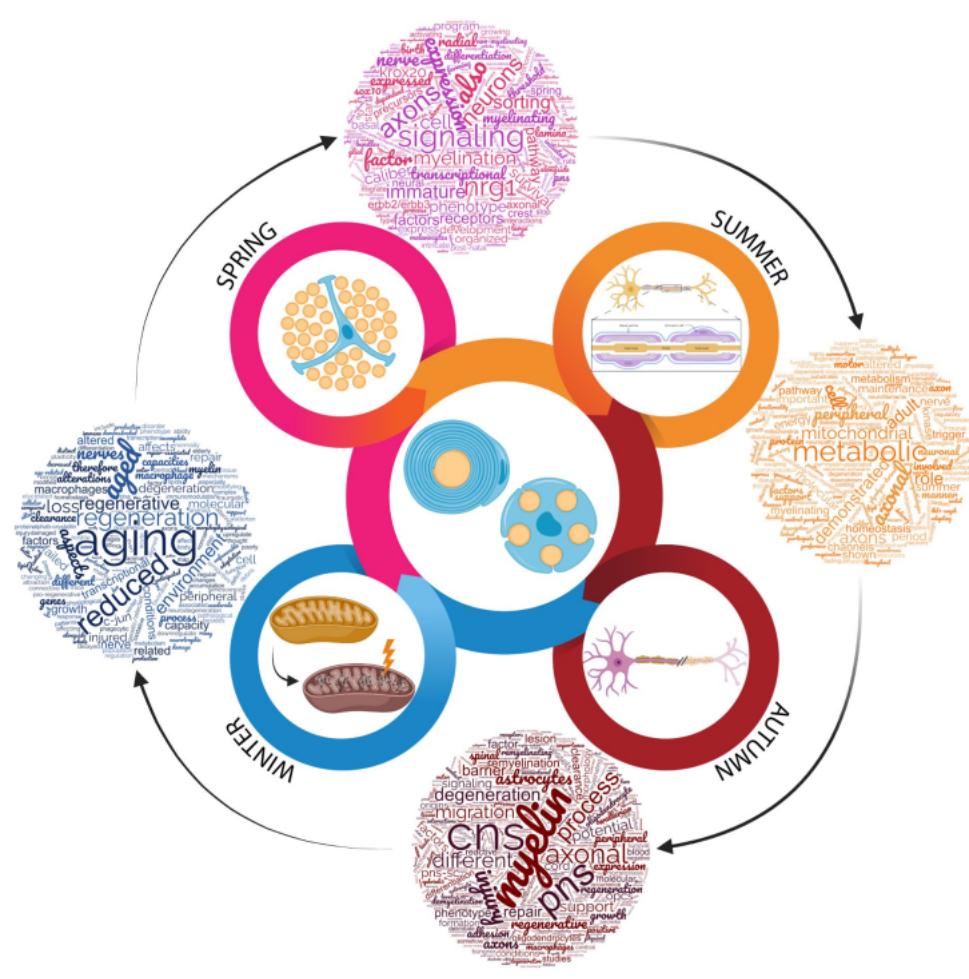

Figure 1. Dynamic art correlating the Schwann cell biological stages with the four seasons. 


\section{Closing Remarks}

Schwann cells are vital for peripheral nerve development, homeostasis, and multiple degenerative and pro-regenerative responses. The full understanding of the role of Schwann cells in peripheral nerve health, senescence, and disease is an exciting field for deciphering how this glia underlies nerve integrity and pathology. This knowledge is necessary for developing effective strategies to restore the homeostasis of peripheral nerves, as well as its regenerative capacity after any disturbance. In particular, it becomes a great challenge when tissue segments are lost. Combined strategies for nerve regeneration using Schwann cells have been successfully developed over the last four decades, but unfortunately come with partial regain of function and are often followed by drawbacks, such as neuropathic pain or paraparesis. The comprehension of Schwann cell biology before or at least with the development of a new regenerative strategy is a careful scientific way to understand, step-by-step, the evolution of nerve tissue replacement and functional recovery.

Funding: This study was supported by the Coordenação de Aperfeiçoamento de Pessoal de Nível Superior (CAPES), Fundação Carlos Chagas Filho de Amparo à Pesquisa do Estado do Rio de Janeiro (FAPERJ), and Conselho Nacional de Desenvolvimento Científico e Tecnológico (CNPq).

Institutional Review Board Statement: Not applicable.

Informed Consent Statement: Not applicable.

Data Availability Statement: Not available.

Conflicts of Interest: The authors declare no conflict of interest.

\section{References}

1. Jessen, K.R.; Mirsky, R.; Lloyd, A.C. Schwann Cells: Development and Role in Nerve Repair. Cold Spring Harb. Perspect. Biol. 2015, 7, 1-15. [CrossRef] [PubMed]

2. Scheib, J.; Höke, A. Advances in peripheral nerve regeneration. Nat. Rev. Neurol. 2013, 9, 668-676. [CrossRef] [PubMed]

3. Mietto, B.S.; Kroner, X.A.; Girolami, E.I.; Santos-Nogueira, X.E.; Zhang, J.; David, S.; David, S. Role of IL-10 in Resolution of Inflammation and Functional Recovery after Peripheral Nerve Injury. J. Neurosci. 2015, 35, 16431-16442. [CrossRef] [PubMed]

4. Arthur-Farraj, P.J.; Latouche, M.; Wilton, D.K.; Quintes, S.; Chabrol, E.; Banerjee, A.; Woodhoo, A.; Jenkins, B.; Rahman, M.; Turmaine, M.; et al. c-Jun Reprograms Schwann Cells of Injured Nerves to Generate a Repair Cell Essential for Regeneration. Neuron 2012, 75, 633-647. [CrossRef]

5. Fontana, X.; Hristova, M.; Da Costa, C.; Patodia, S.; Thei, L.; Makwana, M.; Spencer-Dene, B.; Latouche, M.; Mirsky, R.; Jessen, K.R.; et al. c-Jun in Schwann cells promotes axonal regeneration and motoneuron survival via paracrine signaling. J. Cell Biol. 2012, 198, 127-141. [CrossRef]

6. Viader, A.; Sasaki, Y.; Kim, S.; Strickland, A.; Workman, C.S.; Yang, K.; Gross, R.W.; Milbrandt, J. Aberrant Schwann Cell Lipid Metabolism Linked to Mitochondrial Deficits Leads to Axon Degeneration and Neuropathy. Neuron 2013, 77, 886-898. [CrossRef]

7. Babetto, E.; Wong, K.M.; Beirowski, B. A glycolytic shift in Schwann cells supports injured axons. Nat. Neurosci. 2020, 23, 1215-1228. [CrossRef]

8. Court, F.A.; Coleman, M.P. Mitochondria as a central sensor for axonal degenerative stimuli. Trends Neurosci. 2012, 35, 364-372. [CrossRef]

9. Joseph, N.M.; Mukouyama, Y.-S.; Mosher, J.T.; Jaegle, M.; Crone, S.; Dormand, E.-L.; Lee, K.-F.; Meijer, D.; Anderson, D.J.; Morrison, S.J. Neural crest stem cells undergo multilineage differentiation in developing peripheral nerves to generate endoneurial fibroblasts in addition to Schwann cells. Development 2004, 131, 5599-5612. [CrossRef]

10. Luo, R.; Gao, J.; Wehrle-Haller, B.; Henion, P.D. Molecular identification of distinct neurogenic and melanogenic neural crest sublineages. Development 2003, 130, 321-330. [CrossRef]

11. Jessen, K.; Brennan, A.; Morgan, L.; Mirsky, R.; Kent, A.; Hashimoto, Y.; Gavrilovic, J. The schwann cell precursor and its fate: A study of cell death and differentiation during gliogenesis in rat embryonic nerves. Neuron 1994, 12, 509-527. [CrossRef]

12. Weston, J.A. A radioautographic analysis of the migration and localization of trunk neural crest cells in the chick. Dev. Biol. 1963, 6, 279-310. [CrossRef]

13. Le Douarin, N.M.; Teillet, M.-A.M. Experimental analysis of the migration and differentiation of neuroblasts of the autonomic nervous system and of neurectodermal mesenchymal derivatives, using a biological cell marking technique. Dev. Biol. 1974, 41, 162-184. [CrossRef]

14. Piccolo, S.; Sasai, Y.; Lu, B.; De Robertis, E. Dorsoventral Patterning in Xenopus: Inhibition of Ventral Signals by Direct Binding of Chordin to BMP-4. Cell 1996, 86, 589-598. [CrossRef] 
15. Zimmerman, L.B.; De Jesús-Escobar, J.M.; Harland, R.M. The Spemann Organizer Signal noggin Binds and Inactivates Bone Morphogenetic Protein 4. Cell 1996, 86, 599-606. [CrossRef]

16. Chang, C.; Hemmati-Brivanlou, A. Neural Crest Induction by Xwnt7B in Xenopus. Dev. Biol. 1998, 194, 129-134. [CrossRef]

17. García-Castro, M.I.; Marcelle, C.; Bronner-Fraser, M. Ectodermal Wnt Function as a Neural Crest Inducer. Science 2002, 297, 848-851. [CrossRef]

18. LaBonne, C.; Bronner-Fraser, M. Neural crest induction in Xenopus: Evidence for a two-signal model. Development 1998, 125, 2403-2414. [CrossRef]

19. Mayor, R.; Guerrero, N.; Martínez, C. Role of FGF and Noggin in Neural Crest Induction. Dev. Biol. 1997, 189, 1-12. [CrossRef]

20. Monsoro-Burq, A.-H.; Fletcher, R.B.; Harland, R.M. Neural crest induction by paraxial mesoderm in Xenopus embryos requires FGF signals. Dev. 2003, 130, 3111-3124. [CrossRef]

21. Steventon, B.; Araya, C.; Linker, C.; Kuriyama, S.; Mayor, R. Differential requirements of BMP and Wnt signalling during gastrulation and neurulation define two steps in neural crest induction. Development 2009, 136, 771-779. [CrossRef]

22. Villanueva, S.; Glavic, A.; Ruiz, P.; Mayor, R. Posteriorization by FGF, Wnt, and Retinoic Acid Is Required for Neural Crest Induction. Dev. Biol. 2002, 241, 289-301. [CrossRef]

23. Brennan, A.; Dean, C.; Zhang, A.; Cass, D.; Mirsky, R.; Jessen, K. Endothelins Control the Timing of Schwann Cell Generation in Vitro and in Vivo. Dev. Biol. 2000, 227, 545-557. [CrossRef]

24. Meyer, D.; Birchmeier, C. Erratum: Multiple essential functions of neuregulin in development. Nat. Cell Biol. 1995, 378, 386-390. [CrossRef]

25. Meyer, D.; Yamaai, T.; Garratt, A.; Riethmacher-Sonnenberg, E.; Kane, D.; Theill, L.E.; Birchmeier, C. Isoform-specific expression and function of neuregulin. Development 1997, 124, 3575-3586. [CrossRef]

26. Riethmacher, D.; Sonnenberg-Riethmacher, E.; Brinkmann, V.; Yamaai, T.; Lewin, G.R.; Birchmeier, C. Severe neuropathies in mice with targeted mutations in the ErbB3 receptor. Nat. Cell Biol. 1997, 389, 725-730. [CrossRef]

27. Wolpowitz, D.; Mason, T.B.; Dietrich, P.; Mendelsohn, M.; A Talmage, D.; Role, L.W. Cysteine-Rich Domain Isoforms of the Neuregulin-1 Gene Are Required for Maintenance of Peripheral Synapses. Neuron 2000, 25, 79-91. [CrossRef]

28. Woodhoo, A.; Alonso, M.B.D.; Droggiti, A.; Turmaine, M.; D’Antonio, M.; Parkinson, D.B.; Wilton, D.K.; Al-Shawi, R.; Simons, P.; Shen, J.; et al. Notch controls embryonic Schwann cell differentiation, postnatal myelination and adult plasticity. Nat. Neurosci. 2009, 12, 839-847. [CrossRef]

29. Britsch, S.; Goerich, D.E.; Riethmacher, D.; Peirano, R.I.; Rossner, M.; Nave, K.-A.; Birchmeier, C.; Wegner, M. The transcription factor Sox10 is a key regulator of peripheral glial development. Genes Dev. 2001, 15, 66-78. [CrossRef]

30. Sauka-Spengler, T.; Bronner-Fraser, M. A gene regulatory network orchestrates neural crest formation. Nat. Rev. Mol. Cell Biol. 2008, 9, 557-568. [CrossRef]

31. Dong, Z.; Brennan, A.; Liu, N.; Yarden, Y.; Lefkowitz, G.; Mirsky, R.; Jessen, K.R. Neu differentiation factor is a neuron-glia signal and regulates survival, proliferation, and maturation of rat schwann cell precursors. Neuron 1995, 15, 585-596. [CrossRef]

32. Winseck, A.K.; Caldero, J.; Ciutat, D.; Prevette, D.; Scott, S.A.; Wang, G.; Esquerda, J.E.; Oppenheim, R.W. In Vivo Analysis of Schwann Cell Programmed Cell Death in the Embryonic Chick: Regulation by Axons and Glial Growth Factor. J. Neurosci. 2002, 22, 4509-4521. [CrossRef] [PubMed]

33. Moore, M.W.; Klein, R.D.; Fariñas, I.; Sauer, H.; Armanini, M.; Phillips, H.; Reichardt, L.F.; Ryan, A.M.; Carver-Moore, K.; Rosenthal, A. Renal and neuronal abnormalities in mice lacking GDNF. Nat. Cell Biol. 1996, 382, 76-79. [CrossRef]

34. Morris, J.K.; Lin, W.; Hauser, C.; Marchuk, Y.; Getman, D.; Lee, K.-F. Rescue of the Cardiac Defect in ErbB2 Mutant Mice Reveals Essential Roles of ErbB2 in Peripheral Nervous System Development. Neuron 1999, 23, 273-283. [CrossRef]

35. Verdi, J.; Groves, A.; Fariñas, I.; Jones, K.; Marchionni, M.; Reichardt, L.; Anderson, D. A Reciprocal Cell-Cell Interaction Mediated by NT-3 and Neuregulins Controls the Early Survival and Development of Sympathetic Neuroblasts. Neuron 1996, 16, 515-527. [CrossRef]

36. Woldeyesus, M.T.; Britsch, S.; Riethmacher, D.; Xu, L.; Sonnenberg-Riethmacher, E.; Abou-Rebyeh, F.; Harvey, R.; Caroni, P.; Birchmeier, C. Peripheral nervous system defects in erbB2 mutants following genetic rescue of heart development. Genes Dev. 1999, 13, 2538-2548. [CrossRef]

37. Dowsing, B.J.; Morrison, W.A.; Nicola, N.A.; Starkey, G.P.; Bucci, T.; Kilpatrick, T.J. Leukemia Inhibitory Factor Is an Autocrine Survival Factor for Schwann Cells. J. Neurochem. 1999, 73, 96-104. [CrossRef]

38. Meier, C.; Parmantier, E.; Brennan, A.; Mirsky, R.; Jessen, K.R. Developing Schwann Cells Acquire the Ability to Survive without Axons by Establishing an Autocrine Circuit Involving Insulin-Like Growth Factor, Neurotrophin-3, and Platelet-Derived Growth Factor-BB. J. Neurosci. 1999, 19, 3847-3859. [CrossRef]

39. Weiner, J.; Chun, J. Schwann cell survival mediated by the signaling phospholipid lysophosphatidic acid. Proc. Natl. Acad. Sci. USA 1999, 96, 5233-5238. [CrossRef]

40. Mukouyama, Y.-S.; Shin, D.; Britsch, S.; Taniguchi, M.; Anderson, D.J. Sensory Nerves Determine the Pattern of Arterial Differentiation and Blood Vessel Branching in the Skin. Cell 2002, 109, 693-705. [CrossRef]

41. Mukouyama, Y.-S.; Gerber, H.-P.; Ferrara, N.; Gu, C.; Anderson, D.J. Peripheral nerve-derived VEGF promotes arterial differentiation via neuropilin 1-mediated positive feedback. Development 2005, 132, 941-952. [CrossRef] 
42. Parmantier, E.; Lynn, B.; Lawson, D.; Turmaine, M.; Namini, S.S.; Chakrabarti, L.; McMahon, A.P.; Jessen, K.R.; Mirsky, R. Schwann Cell-Derived Desert Hedgehog Controls the Development of Peripheral Nerve Sheaths. Neuron 1999, $23,713-724$. [CrossRef]

43. Webster, H.D.; Martin, J.R.; O'Connell, M.F. The relationships between interphase Schwann cells and axons before myelination: A quantitative electron microscopic study. Dev. Biol. 1973, 32, 401-416. [CrossRef]

44. Feltri, M.L.; Poitelon, Y.; Previtali, S.C. How Schwann Cells Sort Axons. Neuroscience 2016, 22, 252-265. [CrossRef]

45. Poitelon, Y.; Lopez-Anido, C.; Catignas, K.; Berti, C.; Palmisano, M.; Williamson, C.; Ameroso, D.; Abiko, K.; Hwang, Y.; Gregorieff, A.; et al. YAP and TAZ control peripheral myelination and the expression of laminin receptors in Schwann cells. Nat. Neurosci. 2016, 19, 879-887. [CrossRef]

46. Berti, C.; Bartesaghi, L.; Ghidinelli, M.; Zambroni, D.; Figlia, G.; Chen, Z.-L.; Quattrini, A.; Wrabetz, L.; Feltri, M.L. Non-redundant function of dystroglycan and $\beta 1$ integrins in radial sorting of axons. Development 2011, 138, 4025-4037. [CrossRef]

47. Grigoryan, T.; Stein, S.; Qi, J.; Wende, H.; Garratt, A.N.; Nave, K.-A.; Birchmeier, C.; Birchmeier, W. Wnt/Rspondin/ $\beta$-catenin signals control axonal sorting and lineage progression in Schwann cell development. Proc. Natl. Acad. Sci. USA 2013, 110, 18174-18179. [CrossRef]

48. Pellegatta, M.; De Arcangelis, A.; D’Urso, A.; Nodari, A.; Zambroni, D.; Ghidinelli, M.; Matafora, V.; Williamson, C.; GeorgesLabouesse, E.; Kreidberg, J.; et al. $\alpha 6 \beta 1$ and $\alpha 7 \beta 1$ integrins are required in Schwann cells to sort axons. J. Neurosci. 2013, 33, 17995-18007. [CrossRef]

49. Rasi, K.; Hurskainen, M.; Kallio, M.; Stavén, S.; Sormunen, R.; Heape, A.M.; Avila, R.L.; Kirschner, D.; Muona, A.; Tolonen, U.; et al. Lack of Collagen XV Impairs Peripheral Nerve Maturation and, When Combined with Laminin-411 Deficiency, Leads to Basement Membrane Abnormalities and Sensorimotor Dysfunction. J. Neurosci. 2010, 30, 14490-14501. [CrossRef]

50. Wallquist, W.; Plantman, S.; Thams, S.; Thyboll, J.; Kortesmaa, J.; Lännergren, J.; Domogatskaya, A.; Ögren, S.O.; Risling, M.; Hammarberg, H.; et al. Impeded Interaction between Schwann Cells and Axons in the Absence of Laminin 4. J. Neurosci. 2005, 25, 3692-3700. [CrossRef]

51. Yang, D.; Bierman, J.; Tarumi, Y.S.; Zhong, Y.-P.; Rangwala, R.; Proctor, T.M.; Miyagoe-Suzuki, Y.; Takeda, S.; Miner, J.H.; Sherman, L.S.; et al. Coordinate control of axon defasciculation and myelination by laminin-2 and -8. J. Cell Biol. 2005, 168, 655-666. [CrossRef]

52. Taveggia, C.; Zanazzi, G.; Petrylak, A.; Yano, H.; Rosenbluth, J.; Einheber, S.; Xu, X.; Esper, R.M.; Loeb, J.A.; Shrager, P.; et al. Neuregulin-1 Type III Determines the Ensheathment Fate of Axons. Neuron 2005, 47, 681-694. [CrossRef]

53. Michailov, G.V.; Sereda, M.W.; Brinkmann, B.G.; Fischer, T.M.; Haug, B.; Birchmeier, C.; Role, L.; Lai, C.; Schwab, M.H.; Nave, K.-A. Axonal Neuregulin-1 Regulates Myelin Sheath Thickness. Science 2004, 304, 700-703. [CrossRef]

54. Ghislain, J.; Desmarquet-Trin-Dinh, C.; Jaegle, M.; Meijer, D.; Charnay, P.; Frain, M. Characterisation of cis-acting sequences reveals a biphasic, axon-dependent regulation of Krox20 during Schwann cell development. Development 2002, 129, 155-166. [CrossRef]

55. Ghislain, J.; Charnay, P. Control of myelination in Schwann cells: aKrox20 cis-regulatory element integrates Oct6, Brn2 and Sox10 activities. EMBO Rep. 2006, 7, 52-58. [CrossRef]

56. Kuhlbrodt, K.; Herbarth, B.; Sock, E.; Enderich, J.; Hermans-Borgmeyer, I.; Wegner, M. Cooperative Function of POU Proteins and SOX Proteins in Glial Cells. J. Biol. Chem. 1998, 273, 16050-16057. [CrossRef]

57. Kao, S.-C.; Wu, H.; Xie, J.; Chang, C.-P.; Ranish, J.A.; Graef, I.A.; Crabtree, G.R. Calcineurin/NFAT Signaling Is Required for Neuregulin-Regulated Schwann Cell Differentiation. Science 2009, 323, 651-654. [CrossRef]

58. He, Y.; Kim, J.Y.; Dupree, J.; Tewari, A.; Melendez-Vasquez, C.; Svaren, J.; Casaccia, P. Yy1 as a molecular link between neuregulin and transcriptional modulation of peripheral myelination. Nat. Neurosci. 2010, 13, 1472-1480. [CrossRef]

59. Decker, L.; Desmarquet-Trin-Dinh, C.; Taillebourg, E.; Ghislain, J.; Vallat, J.-M.; Charnay, P. Peripheral Myelin Maintenance Is a Dynamic Process Requiring Constant Krox20 Expression. J. Neurosci. 2006, 26, 9771-9779. [CrossRef]

60. Murphy, P.; Topilko, P.; Schneider-Maunoury, S.; Seitanidou, T.; Evercooren, A.B.-V.; Charnay, P. The regulation of Krox-20 expression reveals important steps in the control of peripheral glial cell development. Development 1996, 122, 2847-2857. [CrossRef]

61. Topilko, P.; Schneider-Maunoury, S.; Levi, G.; Evercooren, A.B.-V.; Chennoufi, A.B.Y.; Seitanidou, T.; Babinet, C.; Charnay, P. Krox-20 controls myelination in the peripheral nervous system. Nat. Cell Biol. 1994, 371, 796-799. [CrossRef] [PubMed]

62. Beirowski, B. The LKB1-AMPK and mTORC1 Metabolic Signaling Networks in Schwann Cells Control Axon Integrity and Myelination: Assembling and upholding nerves by metabolic signaling in Schwann cells. BioEssays 2018, 41, 1-11. [CrossRef] [PubMed]

63. Mietto, B.S.; Mostacada, K.; Maria, A.; Martinez, B. Neurotrauma and Inflammation: CNS and PNS Responses. Mediat. Inflamm. 2015, 2015, 251204. [CrossRef] [PubMed]

64. de Waegh, S.M.; Lee, V.M.-Y.; Brady, S.T. Local modulation of neurofilament phosphorylation, axonal caliber, and slow axonal transport by myelinating Schwann cells. Cell 1992, 68, 451-463. [CrossRef]

65. Yin, X.; Crawford, T.O.; Griffin, J.W.; Tu, P.-H.; Lee, V.M.-Y.; Li, C.; Roder, J.; Trapp, B.D. Myelin-Associated Glycoprotein Is a Myelin Signal that Modulates the Caliber of Myelinated Axons. J. Neurosci. 1998, 18, 1953-1962. [CrossRef]

66. Deerinck, T.J.; Levinson, S.R.; Bennett, G.V.; Ellisman, M.H. Clustering of Voltage-Sensitive Sodium Channels on Axons Is Independent of Direct Schwann Cell Contact in the Dystrophic Mouse. J. Neurosci. 1997, 17, 5080-5088. [CrossRef] 
67. Hinson, A.; Gu, X.; Dib-Hajj, S.; Black, J.; Waxman, S. Schwann cells modulate sodium channel expression in spinal sensory neurons in vitro. Glia 1997, 21, 339-349. [CrossRef]

68. Brushart, T.M.; Aspalter, M.; Griffin, J.W.; Redett, R.; Hameed, H.; Zhou, C.; Wright, M.; Vyas, A.; Höke, A. Schwann cell phenotype is regulated by axon modality and central-Location, and persists in vitro. Exp. Neurol. 2013, 247, 272-281. [CrossRef]

69. Hoke, A.; Redett, R.; Hameed, H.; Jari, R.; Zhou, C.; Li, Z.B.; Griffin, J.W.; Brushart, T.M. Schwann Cells Express Motor and Sensory Phenotypes That Regulate Axon Regeneration. J. Neurosci. 2006, 26, 9646-9655. [CrossRef]

70. Fünfschilling, U.; Supplie, L.M.; Mahad, D.; Boretius, S.; Saab, A.S.; Edgar, J.; Brinkmann, B.G.; Kassmann, C.M.; Tzvetanova, I.D.; Möbius, W.; et al. Glycolytic oligodendrocytes maintain myelin and long-term axonal integrity. Nature 2012, 485, 517-521. [CrossRef]

71. Lee, Y.; Morrison, B.M.; Li, Y.; Lengacher, S.; Farah, M.H.; Hoffman, P.N.; Liu, Y.; Tsingalia, A.; Jin, L.; Zhang, P.-W.; et al. Oligodendroglia metabolically support axons and contribute to neurodegeneration. Nature 2012, 487, 443-448. [CrossRef]

72. Viader, A.; Golden, J.; Baloh, R.H.; Schmidt, R.E.; Hunter, D.A.; Milbrandt, J. Schwann Cell Mitochondrial Metabolism Supports Long-Term Axonal Survival and Peripheral Nerve Function. J. Neurosci. 2011, 31, 10128-10140. [CrossRef]

73. Kline, R.A.; Dissanayake, K.N.; Hurtado, M.L.; Martínez, N.; Ahl, A.; Mole, A.J.; Lamont, D.J.; Court, F.A.; Ribchester, R.R.; Wishart, T.; et al. Altered mitochondrial bioenergetics are responsible for the delay in Wallerian degeneration observed in neonatal mice. Neurobiol. Dis. 2019, 130, 104496. [CrossRef]

74. Kalichman, M.W.; Powell, H.C.; Mizisin, A.P. Reactive, degenerative, and proliferative Schwann cell responses in experimental galactose and human diabetic neuropathy. Acta Neuropathol. 1998, 95, 47-56. [CrossRef]

75. Mietto, B.S.; Jhelum, P.; Schulz, K.; David, S. Schwann cells provide iron to axonal mitochondria and its role in nerve regeneration. J. Neurosci. 2021, 41, 7300-7313. [CrossRef]

76. Beirowski, B.; Babetto, E.; Golden, J.; Chen, Y.-J.; Yang, K.; Gross, R.W.; Patti, G.J.; Milbrandt, J. Metabolic regulator LKB1 is crucial for Schwann cell-mediated axon maintenance. Nat. Neurosci. 2014, 17, 1351-1361. [CrossRef]

77. Lutz, A.B.; Barres, B.A. Contrasting the Glial Response to Axon Injury in the Central and Peripheral Nervous Systems. Dev. Cell 2014, 28, 7-17. [CrossRef]

78. Stassart, R.M.; Woodhoo, A. Axo-glial interaction in the injured PNS. Dev. Neurobiol. 2021, 81, 490-506. [CrossRef]

79. Gomez-Sanchez, J.A.; Pilch, K.S.; Van Der Lans, M.; Fazal, S.V.; Benito, C.; Wagstaff, L.; Mirsky, R.; Jessen, K.R. After Nerve Injury, Lineage Tracing Shows That Myelin and Remak Schwann Cells Elongate Extensively and Branch to Form Repair Schwann Cells, Which Shorten Radically on Remyelination. J. Neurosci. 2017, 37, 9086-9099. [CrossRef]

80. Griffin, J.W.; Thompson, W.J. Biology and pathology of nonmyelinating Schwann cells. Glia 2008, 56, 1518-1531. [CrossRef]

81. Waller, A. XX. Experiments on the section of the glossopharyngeal and hypoglossal nerves of the frog, and observations of the alterations produced thereby in the structure of their primitive fibres. Philos. Trans. R. Soc. Lond. 1850, 140, 423-429. [CrossRef]

82. Bignami, A.; Ralston, H.J. The cellular reaction to wallerian degeneration in the central nervous system of the cat. Brain Res. 1969, 13, 444-461. [CrossRef]

83. George, R.; Griffin, J.W. Delayed Macrophage Responses and Myelin Clearance during Wallerian Degeneration in the Central Nervous System: The Dorsal Radiculotomy Model. Exp. Neurol. 1994, 129, 225-236. [CrossRef] [PubMed]

84. Lampert, P.W.; Cressman, M.R. Fine-structural changes of myelin sheaths after axonal degeneration in the spinal cord of rats. Am. J. Pathol. 1966, 49, 1139-1155.

85. Perry, V.H.; Brown, M.C.; Gordon, S. The macrophage response to central and peripheral nerve injury. A possible role for macrophages in regeneration. J. Exp. Med. 1987, 165, 1218-1223. [CrossRef]

86. Beirowski, B.; Adalbert, R.; Wagner, D.; Grumme, D.S.; Addicks, K.; Ribchester, R.R.; Coleman, M.P. The progressive nature of Wallerian degeneration in wild-type and slow Wallerian degeneration (WldS) nerves. BMC Neurosci. 2005, 6, 6. [CrossRef]

87. Griffin, J.W.; George, R.; Lobato, C.; Tyor, W.R.; Li, C.Y.; Glass, J.D. Macrophage responses and myelin clearance during Wallerian degeneration: Relevance to immune-mediated demyelination. J. Neuroimmunol. 1992, 40, 153-165. [CrossRef]

88. Becerra, J.L.; Puckett, W.R.; Hiester, E.D.; Quencer, R.M.; E Marcillo, A.; Post, M.J.; Bunge, R.P. MR-pathologic comparisons of wallerian degeneration in spinal cord injury. Am. J. Neuroradiol. 1995, 16, 125-133.

89. Buss, A.; Brook, G.A.; Kakulas, B.; Martin, D.; Franzen, R.; Schoenen, J.; Noth, J.; Schmitt, A.B. Gradual loss of myelin and formation of an astrocytic scar during Wallerian degeneration in the human spinal cord. Brain 2004, 127, 34-44. [CrossRef]

90. Mietto, B.S.; Jürgensen, S.; Alves, L.; Pecli, C.; Narciso, M.S.; Assunção-Miranda, I.; Villa-Verde, D.M.S.; Lima, F.R.D.S.; De Menezes, J.R.L.; Benjamim, C.F.; et al. Lack of galectin-3 speeds Wallerian degeneration by altering TLR and pro-inflammatory cytokine expressions in injured sciatic nerve. Eur. J. Neurosci. 2013, 37, 1682-1690. [CrossRef]

91. Lutz, A.B.; Chung, W.-S.; Sloan, S.; Carson, G.A.; Zhou, L.; Lovelett, E.; Posada, S.; Zuchero, J.B.; Barres, B.A. Schwann cells use TAM receptor-mediated phagocytosis in addition to autophagy to clear myelin in a mouse model of nerve injury. Proc. Natl. Acad. Sci. USA 2017, 114, E8072-E8080. [CrossRef]

92. Gomez-Sanchez, J.A.; Carty, L.; Iruarrizaga-Lejarreta, M.; Palomo-Irigoyen, M.; Varela-Rey, M.; Griffith, M.; Hantke, J.; MaciasCamara, N.; Azkargorta, M.; Aurrekoetxea, I.; et al. Schwann cell autophagy, myelinophagy, initiates myelin clearance from injured nerves. J. Cell Biol. 2015, 210, 153-168. [CrossRef]

93. Jang, S.Y.; Shin, Y.K.; Park, S.Y.; Park, J.Y.; Lee, H.J.; Yoo, Y.H.; Kim, J.K.; Park, H.T. Autophagic myelin destruction by Schwann cells during wallerian degeneration and segmental demyelination. Glia 2016, 64, 730-742. [CrossRef] 
94. Napoli, I.; Noon, L.; Ribeiro, S.; Kerai, A.P.; Parrinello, S.; Rosenberg, L.H.; Collins, M.; Harrisingh, M.C.; White, I.J.; Woodhoo, A.; et al. A Central Role for the ERK-Signaling Pathway in Controlling Schwann Cell Plasticity and Peripheral Nerve Regeneration In Vivo. Neuron 2012, 73, 729-742. [CrossRef]

95. Yang, D.P.; Zhang, D.P.; Mak, K.S.; Bonder, D.E.; Pomeroy, S.L.; Kim, H.A. Schwann cell proliferation during Wallerian degeneration is not necessary for regeneration and remyelination of the peripheral nerves: Axon-dependent removal of newly generated Schwann cells by apoptosis. Mol. Cell. Neurosci. 2008, 38, 80-88. [CrossRef]

96. Parkinson, D.B.; Bhaskaran, A.; Arthur-Farraj, P.; Noon, L.A.; Woodhoo, A.; Lloyd, A.C.; Feltri, M.L.; Wrabetz, L.; Behrens, A.; Mirsky, R.; et al. c-Jun is a negative regulator of myelination. J. Cell Biol. 2008, 181, 625-637. [CrossRef]

97. del Río-Hortega, P. La glía de escasa radiaciones (oligodendroglia) [Glia with many processes (oligoden-droglia)]. Trab. Lab. Histol. Patol. 1921, 1, 1-43.

98. Penfield, M.D.W.; Oxon, B.S.C. Oligodendroglia and its relation to classical neuroglia. Brain 1924, 47, 430. [CrossRef]

99. Roots, B.I. The Evolution of Myelinating Cells. In Neuron-Glia Interrelations During Phylogeny: I. Phylogeny and Ontogeny of Glial Cells; Vernadakis, A., Roots, B.I., Eds.; Humana Press: Totowa, NJ, USA, 1995; pp. 223-248. [CrossRef]

100. Chen, M.S.; Huber, A.B.; Van Der Haar, M.E.; Frank, M.; Schnell, L.; Spillmann, A.A.; Christ, F.; Schwab, M.E. Nogo-A is a myelin-associated neurite outgrowth inhibitor and an antigen for monoclonal antibody IN-1. Nat. Cell Biol. 2000, 403, 434-439. [CrossRef]

101. Bandtlow, C.; Zachleder, T.; Schwab, M. Oligodendrocytes arrest neurite growth by contact inhibition. J. Neurosci. 1990, 10, 3837-3848. [CrossRef]

102. McKerracher, L.; David, S.; Jackson, D.; Kottis, V.; Dunn, R.; Braun, P. Identification of myelin-associated glycoprotein as a major myelin-derived inhibitor of neurite growth. Neuron 1994, 13, 805-811. [CrossRef]

103. Barres, B.A.; Jacobson, M.D.; Schmidt, I.R.; Sendtnerf, M.; Raff, M.C. Does oligodendrocyte survival depend on axons? Curr. Biol. 1993, 3, 489-497. [CrossRef]

104. Raine, C.S. On the occurrence of Schwann cells within the normal central nervous system. J. Neurocytol. 1976, 5, 371-380. [CrossRef]

105. Koeppen, A.H.; Ordinario, A.T.; Barron, K.D. Aberrant Intramedullary Peripheral Nerve Fibers. Arch. Neurol. 1968, 18, 567-573. [CrossRef]

106. Blakemore, W.F. Ethidium Bromide Induced Demyelination in the Spinal Cord of the Cat. Neuropathol. Appl. Neurobiol. 1982, 8 , 365-375. [CrossRef]

107. Canto, M.C.D.; Lipton, H.L. Schwann cell remyelination and recurrent demyelination in the central nervous system of mice infected with attenuated Theiler's virus. Am. J. Pathol. 1980, 98, 101-122.

108. Trapp, B.D.; Itoyama, Y.; MacIntosh, T.D.; Quarles, R.H. P2Protein in Oligodendrocytes and Myelin of the Rabbit Central Nervous System. J. Neurochem. 1983, 40, 47-54. [CrossRef] [PubMed]

109. Itoyama, Y.; Ohnishi, A.; Tateishi, J.; Kuroiwa, Y.; De Webster, H.F. Spinal cord multiple sclerosis lesions in Japanese patients: Schwann cell remyelination occurs in areas that lack glial fibrillary acidic protein (GFAP). Acta Neuropathol. 1985, 65, $217-223$. [CrossRef] [PubMed]

110. Wang, Z.H.; Walter, G.F.; Gerhard, L. The expression of nerve growth factor receptor on Schwann cells and the effect of these cells on the regeneration of axons in traumatically injured human spinal cord. Acta Neuropathol. 1996, 91, 180-184. [CrossRef] [PubMed]

111. Black, J.A.; Waxman, S.G.; Smith, K. Remyelination of dorsal column axons by endogenous Schwann cells restores the normal pattern of Nav1.6 and Kv1.2 at nodes of Ranvier. Brain 2006, 129, 1319-1329. [CrossRef] [PubMed]

112. Blight, A.R.; Young, W. Central axons in injured cat spinal cord recover electrophysiological function following remyelination by Schwann cells. J. Neurol. Sci. 1989, 91, 15-34. [CrossRef]

113. Felts, P.; Smith, K. Conduction properties of central nerve fibers remyelinated by Schwann cells. Brain Res. 1992, 574, 178-192. [CrossRef]

114. Gilmore, S.A. Autoradiographic studies of intramedullary schwann cells in irradiated spinal cords of immature rats. Anat. Rec. Adv. Integr. Anat. Evol. Biol. 1971, 171, 517-527. [CrossRef]

115. Gilmore, S.A.; Sims, T.J.; Heard, J.K. Autoradiographic and ultrastructural studies of areas of spinal cord occupied by Schwann cells and Schwann cell myelin. Brain Res. 1982, 239, 365-375. [CrossRef]

116. Griffiths, I.R.; McCulloch, M.C. Nerve fibres in spinal cord impact injuries: Part 1. Changes in the myelin sheath during the initial 5 weeks. J. Neurol. Sci. 1983, 58, 335-349. [CrossRef]

117. Guest, J.D.; Hiester, E.D.; Bunge, P.R. Demyelination and Schwann cell responses adjacent to injury epicenter cavities following chronic human spinal cord injury. Exp. Neurol. 2005, 192, 384-393. [CrossRef]

118. Jasmin, L.; Janni, G.; Moallem, T.M.; Lappi, D.A.; Ohara, P.T. Schwann Cells Are Removed from the Spinal Cord after Effecting Recovery from Paraplegia. J. Neurosci. 2000, 20, 9215-9223. [CrossRef]

119. Raine, C.S.; Traugott, U.; Stone, S.H. Glial bridges and Schwann cell migration during chronic demyelination in the C.N.S. J. Neurocytol. 1978, 7, 541-553. [CrossRef]

120. Sims, T.J.; Durgun, M.B.; Gilmore, S.A. Schwann cell invasion of ventral spinal cord: The effect of irradiation on astrocyte barriers. J. Neuropathol. Exp. Neurol. 1998, 57, 866-873. [CrossRef] 
121. Bachelin, C.; Zujovic, V.; Buchet, D.; Mallet, J.; Evercooren, A.B.-V. Ectopic expression of polysialylated neural cell adhesion molecule in adult macaque Schwann cells promotes their migration and remyelination potential in the central nervous system. Brain 2010, 133, 406-420. [CrossRef]

122. Evercooren, A.B.; Avellana-Adalid, V.; Younes-Chennoufi, A.B.; Gansmüller, A.; Nait-Oumesmar, B.; Vignais, L. Cell-cell interactions during the migration of myelin-forming cells transplanted in the demye-linated spinal cord. Glia 1996, 16, 147-164. [CrossRef]

123. Blakemore, W.F. The effect of sub-dural nerve tissue transplatation on the spinal cord of the rat. Neuropathol. Appl. Neurobiol. 1980, 6, 433-447. [CrossRef]

124. Blakemore, W.F. Limited remyelination of CNS axons by Schwann cells transplanted into the sub-arachnoid space. J. Neurol. Sci. 1984, 64, 265-276. [CrossRef]

125. Blakemore, W.F.; Crang, A.J. The use of cultured autologous Schwann cells to remyelinate areas of persistent demyelination in the central nervous system. J. Neurol. Sci. 1985, 70, 207-223. [CrossRef]

126. Girard, C.; Bemelmans, A.; Dufour, N.; Mallet, J.; Bachelin, C.; Nait-Oumesmar, B.; Evercooren, A.B.-V.; Lachapelle, F. Grafts of Brain-Derived Neurotrophic Factor and Neurotrophin 3-Transduced Primate Schwann Cells Lead to Functional Recovery of the Demyelinated Mouse Spinal Cord. J. Neurosci. 2005, 25, 7924-7933. [CrossRef]

127. Pearse, D.D.; Sanchez, A.R.; Pereira, F.C.; Andrade, C.M.; Puzis, R.; Pressman, Y.; Golden, K.; Kitay, B.M.; Blits, B.; Wood, P.M.; et al. Transplantation of Schwann cells and/or olfactory ensheathing glia into the contused spinal cord: Survival, migration, axon association, and functional recovery. Glia 2007, 55, 976-1000. [CrossRef]

128. Assinck, P.; Duncan, G.J.; Plemel, J.R.; Lee, M.; Stratton, J.A.; Manesh, S.B.; Liu, J.; Ramer, L.M.; Kang, S.H.; Bergles, D.E.; et al. Myelinogenic Plasticity of Oligodendrocyte Precursor Cells following Spinal Cord Contusion Injury. J. Neurosci. 2017, 37, 8635-8654. [CrossRef]

129. Garcia-Diaz, B.; Bachelin, C.; Coulpier, F.; Gerschenfeld, G.; Deboux, C.; Zujovic, V.; Charnay, P.; Topilko, P.; Evercooren, A.B.-V. Blood vessels guide Schwann cell migration in the adult demyelinated CNS through Eph/ephrin signaling. Acta Neuropathol. 2019, 138, 457-476. [CrossRef] [PubMed]

130. Nievergall, E.; Lackmann, M.; Janes, P.W. Eph-dependent cell-cell adhesion and segregation in development and cancer. Cell. Mol. Life Sci. 2012, 69, 1813-1842. [CrossRef] [PubMed]

131. Chaudhry, N.; Bachelin, C.; Zujovic, V.; Hilaire, M.; Baldwin, K.; Follis, R.M.; Giger, R.; Carter, B.D.; Evercooren, A.B.-V.; Filbin, M.T. Myelin-Associated Glycoprotein Inhibits Schwann Cell Migration and Induces Their Death. J. Neurosci. 2017, 37, 5885-5899. [CrossRef] [PubMed]

132. Blakemore, W.F.; Crang, A.J.; Patterson, R.C. Schwann cell remyelination of CNS axons following injection of cultures of CNS cells into areas of persistent demyelination. Neurosci. Lett. 1987, 77, 20-24. [CrossRef]

133. Zawadzka, M.; Rivers, L.E.; Fancy, S.P.; Zhao, C.; Tripathi, R.; Jamen, F.; Young, K.; Goncharevich, A.; Pohl, H.; Rizzi, M.; et al. CNS-Resident Glial Progenitor/Stem Cells Produce Schwann Cells as well as Oligodendrocytes during Repair of CNS Demyelination. Cell Stem Cell 2010, 6, 578-590. [CrossRef]

134. Kegler, K.; Imbschweiler, I.; Ulrich, R.; Kovermann, P.; Fahlke, C.; Deschl, U.; Kalkuhl, A.; Baumgärnter, W.; Wewetzer, K. CNS Schwann cells display oligodendrocyte precursor-like potassium channel activation and antigenic expression in vitro. J. Neural Transm. 2014, 121, 569-581. [CrossRef]

135. Ulanska-Poutanen, J.; Mieczkowski, J.; Zhao, C.; Konarzewska, K.; Kaza, B.; Pohl, H.B.; Bugajski, Ł.; Kaminska, B.; Franklin, R.J.; Zawadzka, M. Injury-induced perivascular niche supports alternative differentiation of adult rodent CNS progenitor cells. eLife 2018, 7, 1-25. [CrossRef]

136. Talbott, J.F.; Loy, D.N.; Liu, Y.; Qiu, M.S.; Bunge, M.B.; Rao, M.S.; Whittemore, S.R. Endogenous Nkx2.2+/Olig2+ oligodendrocyte precursor cells fail to remyelinate the demyelinated adult rat spinal cord in the absence of astrocytes. Exp. Neurol. 2005, 192, 11-24. [CrossRef]

137. de Castro, G.M.; Deja, N.A.; Ma, D.; Zhao, C.; Franklin, R.J.M. Astrocyte Activation via Stat3 Signaling Determines the Balance of Oligodendrocyte versus Schwann Cell Remyelination. Am. J. Pathol. 2015, 185, 2431-2440. [CrossRef]

138. Fraher, J.P. The CNS-PNS transitional zone of the rat. Morphometric studies at cranial and spinal levels. Prog. Neurobiol. 1992, 38, 261-316. [CrossRef]

139. Abbott, N.J.; Rönnbäck, L.; Hansson, E. Astrocyte-endothelial interactions at the blood-brain barrier. Nat. Rev. Neurosci. 2006, 7, 41-53. [CrossRef]

140. Wanner, I.B.; Anderson, M.A.; Song, B.; Levine, J.; Fernandez, A.; Gray-Thompson, Z.; Ao, Y.; Sofroniew, M.V. Glial Scar Borders Are Formed by Newly Proliferated, Elongated Astrocytes That Interact to Corral Inflammatory and Fibrotic Cells via STAT3-Dependent Mechanisms after Spinal Cord Injury. J. Neurosci. 2013, 33, 12870-12886. [CrossRef]

141. Liuzzi, F.J.; Lasek, R.J. Astrocytes Block Axonal Regeneration in Mammals by Activating the Physiological Stop Pathway. Science 1987, 237, 642-645. [CrossRef]

142. Rudge, J.S.; Silver, J. Inhibition of neurite outgrowth on astroglial scars in vitro. J. Neurosci. 1990, 10, 3594-3603. [CrossRef]

143. Faulkner, J.R.; Herrmann, J.E.; Woo, M.J.; Tansey, K.E.; Doan, N.B.; Sofroniew, M.V. Reactive Astrocytes Protect Tissue and Preserve Function after Spinal Cord Injury. J. Neurosci. 2004, 24, 2143-2155. [CrossRef]

144. Clemente, C.D.; Windle, W.F. Regeneration of severed nerve fibers in the spinal cord of the adult cat. J. Comp. Neurol. 1954, 101, 691-731. [CrossRef] 
145. Brown, J.O.; McCouch, G.P. Abortive regeneration of the transected spinal cord. J. Comp. Neurol. 1947, 87, 131-137. [CrossRef]

146. Windle, W.F.; Clemente, C.D.; Chambers, W.W. Inhibition of formation of a glial barrier as a means of permitting a peripheral nerve to grow into the brain. J. Comp. Neurol. 1952, 96, 359-369. [CrossRef] [PubMed]

147. Fairless, R.; Frame, M.C.; Barnett, S.C. N-cadherin differentially determines Schwann cell and olfactory ensheathing cell adhesion and migration responses upon contact with astrocytes. Mol. Cell. Neurosci. 2005, 28, 253-263. [CrossRef]

148. Lavdas, A.A.; Franceschini, I.; Dubois-Dalcq, M.; Matsas, R. Schwann cells genetically engineered to express PSA show enhanced migratory potential without impairment of their myelinating ability in vitro. Glia 2006, 53, 868-878. [CrossRef] [PubMed]

149. Papastefanaki, F.; Chen, J.; Lavdas, A.A.; Thomaidou, D.; Schachner, M.; Matsas, R. Grafts of Schwann cells engineered to express PSA-NCAM promote functional recovery after spinal cord injury. Brain 2007, 130, 2159-2174. [CrossRef] [PubMed]

150. Wilby, M.J.; Muir, E.M.; Fok-Seang, J.; Gour, B.J.; Blaschuk, O.W.; Fawcett, J.W. N-Cadherin Inhibits Schwann Cell Migration on Astrocytes. Mol. Cell. Neurosci. 1999, 14, 66-84. [CrossRef] [PubMed]

151. O'Neill, P.; Lindsay, S.L.; Pantiru, A.; Guimond, S.E.; Fagoe, N.; Verhaagen, J.; Turnbull, J.E.; Riddell, J.S.; Barnett, S.C. Sulfatasemediated manipulation of the astrocyte-Schwann cell interface. Glia 2017, 65, 19-33. [CrossRef]

152. Afshari, F.T.; Kwok, J.C.; Fawcett, J.W. Astrocyte-Produced Ephrins Inhibit Schwann Cell Migration via VAV2 Signaling. J. Neurosci. 2010, 30, 4246-4255. [CrossRef]

153. Grimpe, B.; Pressman, Y.; Bunge, M.B.; Silver, J. The role of proteoglycans in Schwann cell/astrocyte interactions and in regeneration failure at PNS/CNS interfaces. Mol. Cell. Neurosci. 2005, 28, 18-29. [CrossRef]

154. Lakatos, A.; Barnett, S.C.; Franklin, R.J.M. Olfactory ensheathing cells induce less host astrocyte response and chondroitin sulphate proteoglycan expression than schwann cells following transplantation into adult cns white matter. Exp. Neurol. 2003, 184, 237-246. [CrossRef]

155. Plant, G.W.; Bates, M.L.; Bunge, M.B. Inhibitory Proteoglycan Immunoreactivity Is Higher at the Caudal Than the Rostral Schwann Cell Graft-Transected Spinal Cord Interface. Mol. Cell. Neurosci. 2001, 17, 471-487. [CrossRef]

156. Ghirnikar, R.S.; Eng, L.F. Chondroitin sulfate proteoglycan staining in astrocyte-schwann cell co-cultures. Glia 1995, 14, 145-152. [CrossRef]

157. Verdier, V.; Csardi, G.; Smit, A.B.; Verheijen, M.H.G.; Bergmann, S.; Chrast, R.; De Preux-Charles, A.-S.; Médard, J.-J. Aging of myelinating glial cells predominantly affects lipid metabolism and immune response pathways. Glia 2012, 60, 751-760. [CrossRef]

158. Hamilton, R.; Walsh, M.; Singh, R.; Rodriguez, K.; Gao, X.; Rahman, M.; Chaudhuri, A.; Bhattacharya, A. Oxidative damage to myelin proteins accompanies peripheral nerve motor dysfunction in aging C57BL/6 male mice. J. Neurol. Sci. 2016, 370, 47-52. [CrossRef]

159. Lim, E.-M.F.; Musa, A.; Frederick, A.; Ousman, S.S. AlphaB-crystallin expression correlates with aging deficits in the peripheral nervous system. Neurobiol. Aging 2017, 53, 138-149. [CrossRef]

160. Painter, M.W.; Lutz, A.B.; Cheng, Y.-C.; Latremoliere, A.; Duong, K.; Miller, C.M.; Posada, S.; Cobos, E.J.; Zhang, A.X.; Wagers, A.J.; et al. Diminished Schwann Cell Repair Responses Underlie Age-Associated Impaired Axonal Regeneration. Neuron 2014, 83, 331-343. [CrossRef]

161. Kang, H.; Lichtman, J.W. Motor Axon Regeneration and Muscle Reinnervation in Young Adult and Aged Animals. J. Neurosci. 2013, 33, 19480-19491. [CrossRef]

162. Wagstaff, L.J.; Gomez-Sanchez, J.A.; Fazal, S.V.; Otto, G.W.; Kilpatrick, A.M.; Michael, K.; Wong, L.Y.; Ma, K.H.; Turmaine, M.; Svaren, J.; et al. Failures of nerve regeneration caused by aging or chronic denervation are rescued by restoring Schwann cell c-Jun. eLife 2021, 10, 1-32. [CrossRef]

163. Stratton, J.; Eaton, S.; Rosin, N.L.; Jawad, S.; Holmes, A.; Yoon, G.; Midha, R.; Biernaskie, J. Macrophages and Associated Ligands in the Aged Injured Nerve: A Defective Dynamic That Contributes to Reduced Axonal Regrowth. Front. Aging Neurosci. 2020, 12, 1-12. [CrossRef]

164. Scheib, J.L.; Höke, A. An attenuated immune response by Schwann cells and macrophages inhibits nerve regeneration in aged rats. Neurobiol. Aging 2016, 45, 1-9. [CrossRef] 